\title{
Detection of Blast Resistant Gene in Rice by Host-pathogen Interaction and DNA-Marker
}

\author{
Mohammod Hossain ${ }^{1, *}$, Md Ansar Ali², Mohammad Delwar Hossain ${ }^{3}$, Md Abu Taher Mia ${ }^{1}$ \\ ${ }^{1}$ Plant Pathology Division, Bangladesh Rice Research Institute, Bangladesh \\ ${ }^{2}$ Bangladesh Rice Research Institute, Bangladesh \\ ${ }^{3}$ Department of Plant Pathology, Faculty of Agriculture, Bangladesh Agricultural University, Bangladesh
}

Copyright $\bigcirc 2018$ by authors, all rights reserved. Authors agree that this article remains permanently open access under the terms of the Creative Commons Attribution License 4.0 International License

\begin{abstract}
Rice blast disease caused by Pyricularia oryzae is a major disease in Bangladesh. In the search of resistant source against $P$. oryzae, resistant gene ( $R$-gene) was assessed by (i) host-pathogen interaction and (ii) PCR-based screening at the laboratory of Bangladesh Rice Research Institute. One hundred and forty four plant materials were classified into 10 cultivar groups $(\mathrm{CG})$ based on their reaction patterns to four distinct blast isolates (SDBI; standard differential blast isolate) H-11-64, H-1-8, H-1-1 and H-11-67. The reaction patterns of plant materials to these four standard blast isolates indicated presence of Pish, Pi9, Pita2 and Pita genes and their combination in the genetic background of tested plant materials. Gene specific primer 195R-1/195F-1, Pita440 (YL153)/Pita440 (YL154), OSM89 and AOL45/AOL48 were used to identify and confirm the presence of $P i 9$, Pita, Pita2 and Pish genes in plant materials, respectively through PCR-based assay. Plant materials, H13, H23, H25, H35, H47, H49, H136, H138 harbored all three genes, Pita, Pita 2 and Pish in their genetic background. The Pi9 gene together with Pita2 was detected in local rice cultivar $\mathrm{H} 100$ and H129, which were confirmed by DNA analysis in PCR assay. These materials could be used in gene pyramiding in promising high yielding cultivar for durable blast resistance.
\end{abstract}

Keywords Rice, Standard Differential Blast Isolates, $R$-gene, DNA-Marker

\section{Introduction}

Rice (Oryza sativa L.) is the staple food for about half of the world's population. Bangladeshi people take Rice (Oryza sativa L.) as a major food which is central to the economy of the country accounting for about $20 \%$ of GDP (gross domestic product) $[1,2]$ and as more than $90 \%$ of all rice is produced in Asia it is called an Asian crop. Among various factors responsible for low yield of rice, blast caused by $P$. oryzae plays an important role which causes yield loss of $11-15 \%$ worldwide annually [3]. Under climatic changes such as lacking in water, many rice diseases particularly, blast disease of rice may increase [4, 5].

Managing blast disease at farmers' field chemical control is mainly accomplished and other managing options, especially water is mostly difficult to practice [6]. Agricultural land in Bangladesh is declining but population is raising day by day, means that mounting of rice yield must be explored from different approaches. In such situation resistant cultivars is one of the potential ways to control blast pathogen. Innovation of blast $R$-gene in the genomic background of rice plant has created an opportunity to develop durable resistance in rice against blast pathogen [7]. Pyramiding of $R$-gene is needed for development of durable resistant rice cultivars against blast pathogen.

Blast isolates clarified on monogenic lines (ML; single gene resistance to blast pathogen) or differential varieties (DVs) through pathogenicity test indicated that Pi 9 , Pish, Pita and Pita2 were the major genes responsible for blast resistance in Bangladesh which showed resistance frequencies of $80-90 \%$ against all tested blast isolates from the country $[8,9]$. A set of SDBIs (Standard Differential Blast Isolates) has been developed [9] through pathogenicity test.

Huge number of rice entries has been screened in Bangladesh against blast pathogen to identify resistant entries but the gene(s) involved with those entries remains untested. Only one attempt by Khan et al. [8] has so far been made to identify the gene involved in fragrant rice, which is essential for maintaining and utilizing the known gene pool. Interaction between differential varieties and SDBIs (host-pathogen interaction) is used to detect blast $R$-gene in Japan and IRRI $[9,11]$. Molecular technique is also useful to detect blast resistant gene(s) from a large number of rice germplasms $[8,9]$. 
With this view in mind this project has been undertaken to find out source(s) of major blast resistant genes in rice land races through pathogenicity test with standard blast isolates for further breeding program. The study has been aimed to identify the resistant gene in different rice cultivars by gene specific primer through DNA marker analysis.

\section{Materials and Methods}

The experiments were conducted at the experimental plots and Seed Pathology \& molecular laboratory of Plant Pathology Division of Bangladesh Rice Research Institute (BRRI), Gazipur-1701 with the assistance of Department of Plant Pathology, Bangladesh Agricultural University, Mymensingh.

\subsection{Gene Assessment in Rice Land Races Based on Reaction Pattern to Standard Differential Blast Isolates (SDBIs)}

\subsubsection{Collection and Preservation of Standard Differential} Blast Isolates

Four major blast resistant genes named Pi9, Pish, Pita and Pita2 those were previously identified as blast resistant genes in Bangladesh $[8,9]$ was targeted for this research. Four standard differential blast isolates (SDBIs) viz. H-11-64 (incompatible to Pita gene; also Pi9), H-1-8 (incompatible to $\mathrm{Pish}$; also $\mathrm{Pi} 9$ gene), H-1-1 (incompatible to Pita -2 gene) and H-11-67 (incompatible to Pi9 gene) were collected from Hossain [9] to identify those resistant genes in rice land races through pathogenicity test. Modified NIAS (National Institute of Advanced Studies) method [10] was used to preserve blast pathogen.

\subsubsection{Preparation of Plant Materials and Inocula for Inoculation}

Rice land races and susceptible checks (SC; susceptible to blast pathogen) were seeded in seeding cell trays (having 35 holes of seeding options in each tray) for each isolate. Modified NIAS method was followed to prepare plant materials and inocula for inoculation [10]. After growing 2-3 weeks, plants were ready for inoculation (5-6 leaf stage).

\subsubsection{Inoculation of Plant Materials}

The conidial concentration was determined using a hemacytometer and adjusted to $1 \times 10^{5}(100,000)$ conidia per ml. Inoculation was carried out by the NIAS method cited by Hayashi et al. [10]. The inoculated plants were incubated for approximately $24 \mathrm{hr}$ at $25^{\circ} \mathrm{C}$ and then transferred to a screening house (humidity approximately $60 \%)$ at $25-30^{\circ} \mathrm{C}$.

\subsubsection{Disease Assessment Based on Infection Type on Plant}

Phenotypic data from screening result: Susceptible (S) or resistant (R) reaction of the test plants to the SDBIs was assessed by examining the leaves for blast symptoms. Seven days after inoculation, infection type (0-5 scale) was rated where scale 0-3 were resistant for Pish and Pita2; 0-2 were resistant for Pi9 and Pita genes [10,11].

\subsubsection{Sampling of Rice Plants and their Categorization}

Rice plants were sampled based on symptoms on leaves produced by pathogen (susceptible or resistant reaction of plant to specific SDBI). Then plants were categorized or grouped (cultivar group, CG) based on presence or absence of resistant gene in the tested plant materials (Table 2, 3).

\subsection{Gene Assessment in Rice Land Races Based on DNA Marker Analysis}

Major blast resistant genes for Bangladesh $[8,9]$ were surveyed in the background of rice germplasm (including previous 100 rice land races). Gene-specific primers were used to identify and confirm (from section 2.1) the target gene in plant samples (Table 1).

\subsubsection{Selection of Best Primers for Screening Plant Materials to Identify Blast $R$-Gene}

Fifteen gene-specific primers were screened against the target gene of monogenic lines to select the best one. Among the 15 primers, 3 were for Pita gene, 3 for Pita2, 4 for Pish and 5 for $P i 9$ (Table 1). The best primers were used in subsequent study to identify the target gene in studied plant materials. 
Table 1. List of gene-specific primers used in the study

\begin{tabular}{|c|c|c|c|c|}
\hline Gene name & Primer name & primer sequence (Forward) & Primer name & primer sequence (Reverse) \\
\hline \multirow[t]{5}{*}{$\operatorname{Pi9}$} & 195R-1 & ATGGTCCTTTATCTTTATTG & $195 \mathrm{~F}-1$ & TTGCTCCATCTCCTCTGTT \\
\hline & NBS3-F & AGATGTTAGTAGCAAGTTCC & NBS3-R & TGTCAGTTATGTCCAAAGTG \\
\hline & NBS4-F & ACTTTGTTGTGCTTGATAAC & NBS4-R & ATGGTGAACGGTATCTGTAT \\
\hline & $\begin{array}{c}\text { NBS/ } \\
\text { LRR-F2 }\end{array}$ & CACTGTTGTAGCGGAGGAGA & $\begin{array}{c}\text { NBS/ } \\
\text { LRR-R2 }\end{array}$ & CAGTACGCGATTTTCATTGTTC \\
\hline & NBS2-O & TACAACCACCTACCATCCCAT & NBS2-U & TCTAGAACCTGCAAGTCTCG \\
\hline \multirow[t]{3}{*}{ Pita } & $\begin{array}{c}\text { Pita403 } \\
\text { (YL100) }\end{array}$ & CAATGCCGAGTGTGCAAAGG & $\begin{array}{c}\text { Pita403 } \\
\text { (YL102) }\end{array}$ & TCAGGTTGAAGATGCATAGC \\
\hline & $\begin{array}{l}\text { Pita440 } \\
\text { (YL153) }\end{array}$ & CAACAATTTAATCATACACG & $\begin{array}{l}\text { Pita440 } \\
\text { (YL154) }\end{array}$ & ATGACACCCTGC-GATGCAA \\
\hline & $\begin{array}{l}\text { Pita1042 } \\
\text { (YL155) }\end{array}$ & AGCAGGTTATAAGCTAGGCC & $\begin{array}{c}\text { Pita1042 } \\
\text { (YL87) }\end{array}$ & CTACCAACAAGTTCATCAAA \\
\hline \multirow[t]{3}{*}{ Pita2 } & RM155 & GAGATGGCCCCCTCCGTGATGG & RM155 & TGCCCTCAATCGGCCACACCTC \\
\hline & OSM89 & TTGGTCAAAGTTAGCATGGGAGGG & OSM89 & TTTGAACCGGGTGGCCCACATG \\
\hline & RM7102 & TTGAGAGCGTTTTTAGGATG & RM7102 & TCGGTTTACTTGGTTACTCG \\
\hline \multirow[t]{4}{*}{ Pish } & AOL45 & TCAGAAATCCACAGTTGCATGCAC & AOL48 & GGAGAGCTGCTCTATACAATTTATAC \\
\hline & AOL54 & GTGAAAGATTCCACCCAGGTTC & AOL71 & TTGCGCTTCTCCGTAGTAGTG \\
\hline & AOL51 & AGCTGCAGTAGTGCTGTTCCATG & AOL52 & CGTAAGATCATGAGCGAATG \\
\hline & AOL351 & ACTGCCCCAACATAACATCTC & AOL353 & СCTGCAGCTCTTCTTCAAAAG \\
\hline
\end{tabular}

\subsubsection{Plant DNA Extraction and Preparation}

Leaf samples were collected from young leaves of 21-day-old rice plants. DNA was extracted following modified Mini-scale method [12]. The quality and quantity of extracted DNA was assessed by using spectrophotometric method (NanoDrop spectrophotometer; Thermo Fisher Scientific, Wilmington, DE, U.S.A.). Dilution of concentrated DNA was done to make working concentration at $25 \mathrm{ng} / \mu \mathrm{l}$.

\subsubsection{Polymerase Chain Reaction (PCR) for Simple Sequence Repeats (SSRs)}

The PCR was performed in $10 \mu$ reactions containing about 25 ng of DNA template ( $3 \mu$ l DNA with $10 \mathrm{X}$ dilution factor), $1 \mu 1 \mathrm{l}$ X TB buffer (containing $200 \mathrm{mM}$ Tris- $\mathrm{HCl}$ $\mathrm{pH} 8.3,500 \mathrm{mM} \mathrm{KCl}), 1.35 \mu \mathrm{l} 25 \mathrm{mM} \mathrm{MgCl}_{2}, 0.2 \mu \mathrm{l}$ of $10 \mathrm{mM}$ dNTP, $0.5 \mu 1$ each of $10 \mu \mathrm{M}$ forward and reverse primers and $0.1 \mu \mathrm{l}$ of Taq DNA polymerase $(5 \mathrm{U} / \mu \mathrm{l})$ using GStorm thermal cycler. The PCR machine was then be run with $103-112{ }^{\circ} \mathrm{C}$ lid temperature following SSR-PCR protocol [13]. Water was used as negative control for each primer instead of DNA sample. Reference monogenic lines were used as positive control.

\subsubsection{Gel Electrophoresis, Staining and Visualization of the Gel}

The PCR products were visualized by ethidium bromide $(0.5 \mathrm{mg} / \mathrm{ml})$ and agarose gel $(1.5 \%$; $1 \mathrm{X}$ TBE buffer $)$ electrophoresis following the protocol used by Jean-Louis [14]. The stained gel was exposed to UV light in a gel documentation system (BioDocAnalyze, Biometra, An Analytik Jena Company, Goettingen, Germany) and the gel image was saved as a JPEG file.

\section{Results}

\subsection{Gene Assessment in Rice Land Races Based on Reaction Pattern to Standard Blast Isolates}

Tested plant cultivars showed various patterns of reactions to the differential blast isolates. Twenty one cultivars and susceptible checks LTH and US2 were susceptible to all 4 selected isolates and classified as CG I (Table 2). None of the Pita, Pish, Pita2 or Pi9 was estimated in these cultivars. Seven cultivars and differential variety (DV), IRBLta-K1 (harboring Pita gene) showed resistance to a blast isolate H-11-64 (incompatible to Pita gene) and were classified as CG II (Table 2). From this reaction pattern 8 cultivars and differential variety (DV), IRBLsh-B (harboring Pish gene) were classified as CG III and considered to harbor Pish and not to harbor Pita, Pita2 or Pi9. Fifteen cultivars and differential variety (DV), IRBLta2-Pi (harboring Pita2 gene) were resistant to H-1-1 (incompatible to Pita2 gene), but susceptible to other three blast isolates. This cultivar was classified as CG IV and estimated to harbor Pita2 gene but not Pita, Pish or Pi9 (Table 2). IRBL9-W (harboring Pi9 gene) was susceptible to only 1 isolate H-1-1 (compatible to Pig gene) and classified as CG V (Table 2). 
Table 2. Cultivar classification based on reaction pattern to four selected blast isolates

\begin{tabular}{|c|c|c|c|c|c|c|c|c|c|}
\hline \multirow{2}{*}{$\begin{array}{l}\text { Cultivar } \\
\text { Group }(C G)\end{array}$} & \multirow{2}{*}{ Differential variety (DVs) and Cultivar } & \multicolumn{4}{|c|}{ Reaction to SDBI } & \multirow{2}{*}{\multicolumn{4}{|c|}{$\begin{array}{l}\text { Estimated gene(s) harboring } \\
\text { in the genetic background }\end{array}$}} \\
\hline & & $\mathrm{H}-11-64^{\mathrm{A}}$ & $\mathrm{H}-1-8^{\mathrm{B}}$ & $\mathrm{H}-1-1^{\mathrm{C}}$ & $H-11-67^{\mathrm{D}}$ & & & & \\
\hline I & $\begin{array}{c}\text { LTH,US2,H3,H9,H26,H27,H34,H41,H44,H46,H5 } \\
\text { 1,H53,H55,H64,H65,H66,H69,H82,H91,H93,H95 } \\
\text {,H133,H134 }\end{array}$ & $\mathrm{S}$ & $\mathrm{S}$ & $\mathrm{S}$ & $\mathrm{S}$ & - & - & - & - \\
\hline II & IRBLta-K1,H12, H29,H52,H63,H78,H77,H96 & $\mathrm{R}$ & $\mathrm{S}$ & $\mathrm{S}$ & $\mathrm{S}$ & Pita & - & - & - \\
\hline III & IRBLsh-B,H8,H38,H40,H61,H68,H80,H81,H84 & $\mathrm{S}$ & $\mathrm{R}$ & $\mathrm{S}$ & $\mathrm{S}$ & - & Pish & - & - \\
\hline IV & $\begin{array}{c}\text { IRBLta2-Pi, H2,H7,H10,H24,H33,H43,H56,H60, } \\
\text { H62, H73,H74,H85,H98,H99,H139 }\end{array}$ & $\mathrm{S}$ & $\mathrm{S}$ & $\mathrm{R}$ & $\mathrm{S}$ & - & - & Pita 2 & - \\
\hline V & IRBL9-W & $\mathrm{R}$ & $\mathrm{R}$ & $\mathrm{S}$ & $\mathrm{R}$ & - & - & - & $P i 9$ \\
\hline VI & $\mathrm{H} 4, \mathrm{H} 28, \mathrm{H} 36, \mathrm{H} 45, \mathrm{H} 50, \mathrm{H} 67, \mathrm{H} 71, \mathrm{H} 141$ & $\mathrm{R}$ & $\mathrm{R}$ & $\mathrm{S}$ & $\mathrm{S}$ & Pita & Pish & - & - \\
\hline VII & $\begin{array}{c}\mathrm{H1}, \mathrm{H} 11, \mathrm{H} 14, \mathrm{H} 19, \mathrm{H} 31, \mathrm{H} 32, \mathrm{H} 39, \mathrm{H} 48, \mathrm{H} 86, \\
\text { H90, H144 }\end{array}$ & $\mathrm{R}$ & $\mathrm{S}$ & $\mathrm{R}$ & $\mathrm{S}$ & Pita & - & Pita 2 & - \\
\hline VIII & $\begin{array}{c}\text { H15, H16, H18, H21, H22, H37, H42, H57, H58, } \\
\text { H72, H79, H83, H135 }\end{array}$ & $\mathrm{S}$ & $\mathrm{R}$ & $\mathrm{R}$ & $\mathrm{S}$ & - & Pish & Pita 2 & - \\
\hline IX & H13, H23, H25, H35, H47, H49, H136, H138 & $\mathrm{R}$ & $\mathrm{R}$ & $\mathrm{R}$ & $\mathrm{S}$ & Pita & Pish & Pita 2 & - \\
\hline $\mathrm{X}$ & H100,H129 & $\mathrm{R}$ & $\mathrm{R}$ & $\mathrm{R}$ & $\mathrm{R}$ & Pita & Pish & Pita 2 & $\operatorname{Pi} 9$ \\
\hline
\end{tabular}

S' susceptible and R' resistant reaction of host plant to blast isolates; ${ }^{\mathrm{A}}$ Incompatible to Pita (also Pi9); ${ }^{\mathrm{B}}$ Incompatible to Pish (also Pi9); ${ }^{\mathrm{C}}$ Incompatible to Pita $2 ;{ }^{\mathrm{D}}$ Incompatible to $\mathrm{Pi} 9$

Eight cultivars were resistant to blast isolates, H-11-64 and H-1-8 and susceptible to H-1-1 and H-11-67. These cultivars were classified as CG VI and estimated to harbor Pita and Pish genes. Eleven cultivars were resistant to 2 isolates, H-11-64 and H-1-1, and estimated to have Pita and Pita2 genes by primary estimation and classified as CG VII. Thirteen cultivars were resistant to H-1-8 in addition to H-1-1 isolates and estimated to have Pish and Pita2 genes but not Pita or Pi9 genes (CG VIII). Eight cultivars were classified as CG IX and estimated to have Pita, Pish and Pita2 genes together in each of them. Resistance to the blast isolate, H-11-64, H-1-8, H-1-1and H-11-67 in cultivars, H100 and H129 were recorded where all the 4 expected genes, Pita, Pish, Pita2 and Pi9 were expected to be present in those two cultivars. These two cultivars ware classified as CG X (Table 2).

\subsection{Gene Assessment in Rice Land Races Based on DNA Marker Analysis}

\subsubsection{Selection of Best Primers for Screening Plant Materials to Identify Blast $R$-Gene}

The results of selecting primer(s) were presented in Figure 1-3. Four primers, Pita440 (YL153/YL154), OSM89, AOL45/AOL48 and 195R-1/195F-1 produced distinct single bands from the genomic DNA of monogenic lines, IRBLta-CP1, IRBLta2-Pi, IRBLsh-B and IRBL9-W, harboring Pita, Pita2, Pish and Pi9 gene, respectively and were used in subsequent experiment to find out resistant gene in plant materials.

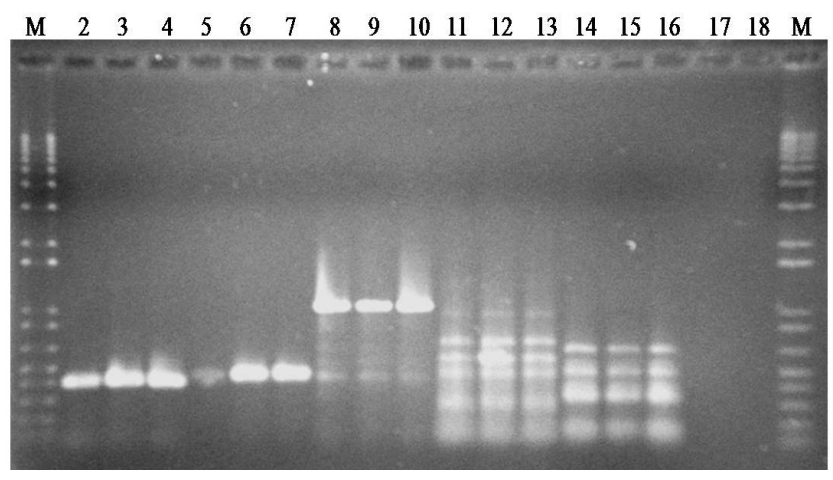

Figure 1. Selection of primer for Pita and Pita2 genes. Lane $1 \& 19$ ladder M (1kb+); 2-4 primer Pita403, 5-7 primer Pita440; 8-10 primer Pita1042 for Pita gene; 11-13 primer RM155 and lane 14-16 primer OSM89 for Pita 2 gene; lane 17 and 18 negative control (LTH)

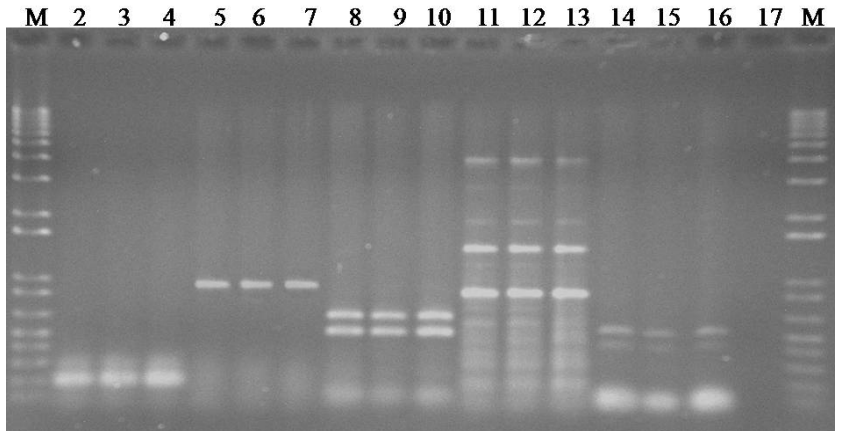

Figure 2. Selection of primer for Pita2 and Pish gene. Lane $1 \& 18$ ladder $(1 \mathrm{~kb}+)$; lane 2-4 primer RM7102 for Pita-2 gene; 5-7 primer AOL45, 8-10 primer AOL54, 11-13 primer AOL51 and 14-16 primer AOL351 for Pish gene; 17 negative control (LTH) 


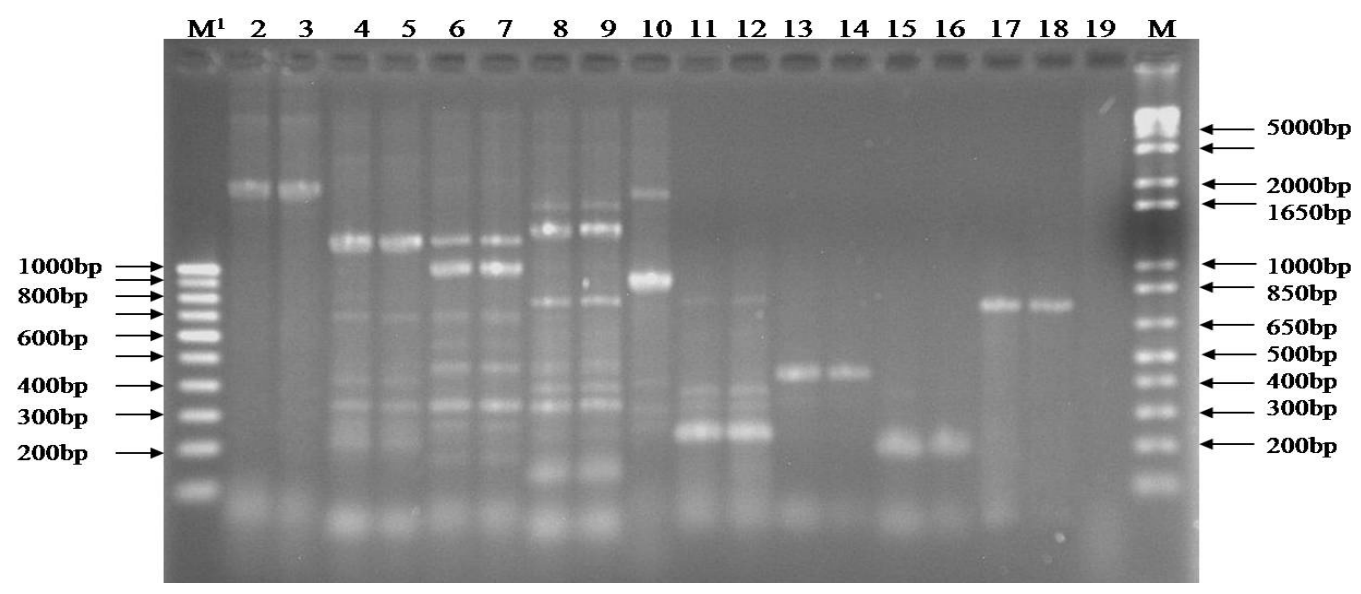

Figure 3. Selection of primer for Pita 2. Lane 1 and 20 ladder (100 bp); lane 2-4 primer RM155, lane 5-7 primer OSM89 and lane 8-10 primer RM7102 where annealing temperature was $65^{\circ} \mathrm{C}$; again lane 11-13 primer RM155, lane 14-16 primer OSM89 and lane 17-18 primer RM7102 where annealing temperature was $70^{\circ} \mathrm{C}$; lane 19 negative control (LTH).

\subsubsection{Genotyping of Pita, Pish, Pita2 and Pi9 Genes in the} Tested Plant Materials Using DNA Markers

One hundred forty four rice plant materials of local land races were screened for the presence of 4 major rice blast resistant $(R)$ genes, Pita, Pish, Pita 2 and Pi9 using the gene specific primers.

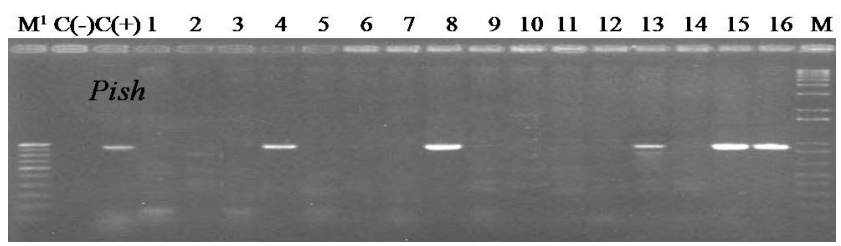

Figure 4. Gel picture (partial) for screening rice land races for blast

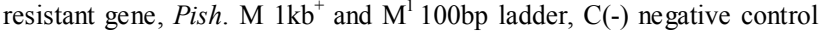
(susceptible check, LTH for no blast resistant gene), $\mathrm{C}(+)$ positive control (resistant check for reference Pish gene), Serial number 1-16 indicates plant samples.

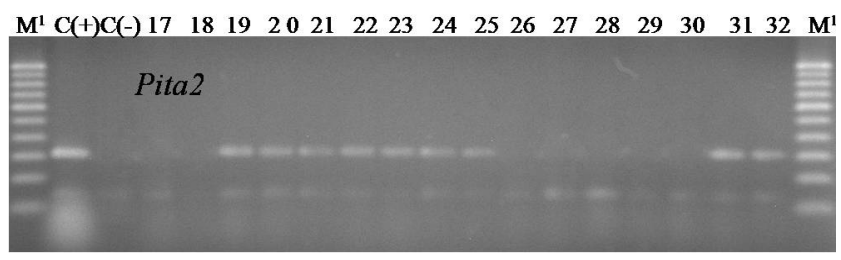

Figure 5. Gel picture (partial) for screening rice land races for blast resistant gene, Pita2. C(-) negative control and $\mathrm{C}(+)$ positive control (resistant check for reference Pita2 gene), Serial 17-32 indicates plant samples.

Genetic diversity of Pish gene was assessed by DNA marker AOL45/AOL48 where forty accessions showed the positive reactions of Pish genes located on chromosome 1 (Figure 4 and Table 3). Out of 144 germplasms, the Pita 2 gene, present in chromosome 1 of rice, was detected in 75 accessions with OSM89 marker (Figure 5 and Table 3). The presence and absence of the Pita gene were estimated using the DNA marker Pita440 (YL153/YL154). The DNA fragments of positive control cultivar, IRBLta-K1 carrying Pita gene were amplified, while those of the negative control, LTH or US2 (both having no blast resistant gene), were not amplified. The Pita gene on chromosome 12 was scored to 76 out of 144 tested plant materials (Figure 6 and Table 3). Genetic diversity of $P i 9$ gene in tested plant materials was assessed by DNA marker 195R-1/195F-1. Only 2 plant materials showed DNA fragments with primer $195 \mathrm{R}-1 / 195 \mathrm{~F}-1$ indicating presence of $P i 9$ in those materials (Table 3 and Figure 7).

Some plant materials consisted of more than one gene. Thirteen plant materials were observed with two genes viz. Pita and Pish. Thirty plant materials were recorded with $R$-gene Pita and Pita2. Resistant gene Pish and Pita2 were present in twelve materials. Three $R$-genes, Pita, Pita 2 and Pish were found together in eleven plant materials. Two materials those were recorded only with $P i 9$ gene also consisted of Pita2 gene (Table 3).

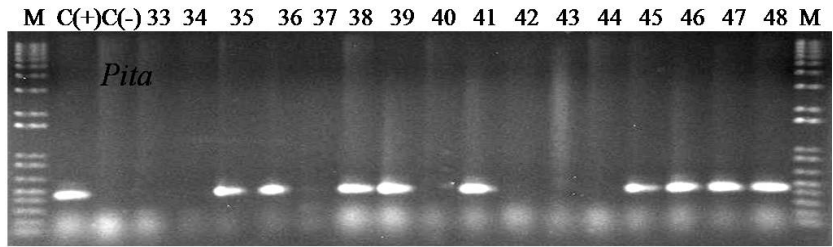

Figure 6. Gel picture (partial) for screening rice land races for blast resistant gene, Pita. C(-) negative control, $\mathrm{C}(+)$ positive control (resistant check for reference Pita gene), Serial number 33-48 indicates plant samples.

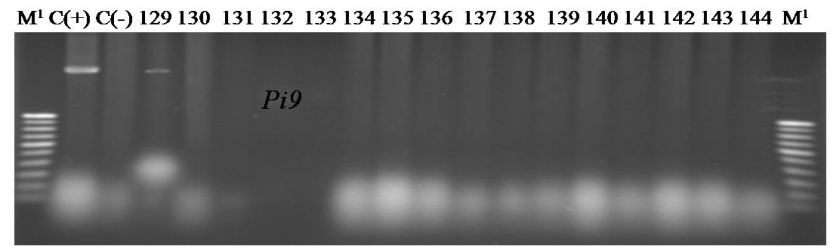

Figure 7. Gel picture (partial) for screening rice land races for blast resistant gene, Pi9. C(-) negative control, $\mathrm{C}(+)$ positive control (resistant check for reference Pish gene), Serial number 129-144 indicates plant samples. 
Table 3. Cultivar classification based on Presence (+) or absence (-) of resistant gene in rice land races assessed by DNA markers

\begin{tabular}{|c|c|c|c|c|c|c|}
\hline \multirow[t]{2}{*}{ CG } & \multirow[t]{2}{*}{ Fr } & \multirow[t]{2}{*}{ DVs and Cultivar } & \multicolumn{4}{|c|}{$\begin{array}{c}\text { Gene(s) harboring in the genetic } \\
\text { background }\end{array}$} \\
\hline & & & Pita & Pish & Pita 2 & Pi9 \\
\hline I & 30 & $\begin{array}{c}\text { LTH, US2,H3,H9,H17,H26,H27,H31,H53,H54,H55,H65,H66, H69, H82, H91, } \\
\text { H92, H93, H94, H109, H110, H111, H112, H114, H115, H118, H119, H121, } \\
\text { H124, H126, H131, H132 }\end{array}$ & - & - & - & - \\
\hline II & 22 & $\begin{array}{c}\text { IRBLta-K1,H12,H29,H30,H32,H41,H46,H51,H52,H63,H70,H75, H76,H77, } \\
\text { H78, H90, H96, H107, H108, H113, H116, H117, H133 }\end{array}$ & + & - & - & - \\
\hline III & 4 & IRBLsh-B,H20, H40, H61, H80 & - & + & - & - \\
\hline IV & 20 & $\begin{array}{c}\text { IRBLta2-Pi, H2, H5, H7, H10,H11, H24, H33, H34, H43, H44, H56, H60, H62, } \\
\text { H64, H95, H98, H104, H128, H134 }\end{array}$ & - & - & + & - \\
\hline V & 0 & IRBL9-W & - & - & - & + \\
\hline VI & 13 & $\mathrm{H} 18, \mathrm{H} 28, \mathrm{H} 36, \mathrm{H} 38, \mathrm{H} 45, \mathrm{H} 50, \mathrm{H} 67, \mathrm{H} 68, \mathrm{H} 71, \mathrm{H} 81, \mathrm{H} 84, \mathrm{H} 127, \mathrm{H} 141$ & + & + & - & - \\
\hline VII & 30 & $\begin{array}{l}\text { H1, H6, H14, H19, H39, H48, H59, H73, H74, H85, H86, H87, H88, H89, H97, } \\
\text { H99, H101, H102, H103, H105, H106, H120, H123, H125, H137, H139, H140, } \\
\text { H142, H143, H144 }\end{array}$ & + & - & + & - \\
\hline VIII & 12 & H8, H1 5, H16, H21, H22, H37, H42, H57, H72, H79, H130, H135 & - & + & + & - \\
\hline IX & 11 & H13, H23, H25, H35, H47, H49, H58, H83, H122, H136, H138 & + & + & + & - \\
\hline $\mathrm{X}$ & 2 & H100, H129 & - & - & + & + \\
\hline 10 & 144 & & 76 & 40 & 75 & 2 \\
\hline
\end{tabular}

\section{Discussion}

Tested rice plant materials of Bangladesh were classified into 10 cultivar groups (CG) based on reaction patterns to four distinct blast isolates, H-11-64, H-1-8, H-1-1 and H-11-67. Significant variations were found among tested plant materials in disease severity to blast, which indicated the existence of a genetic variability of blast resistance in the tested materials. It indicated that materials of these cultivar groups may contain blast-resistant useful genes Pish, Pi9, Pita2 and Pita in their genetic background, because DVs having those similar genes were present in the same cultivar group (Table 2). Kobayashi et al. [15] presented the similar results. The cultivar group CG I having susceptible check indicated that materials of this $\mathrm{CG}$ are highly susceptible to all the 4 selected isolates. None of the Pita, Pish, Pita 2 or $P i 9$ genes supposed to be present in these cultivars. Genotypes belonging to the different cultivar groups maintained genetic variation [16].

Group CG II consisting of IRBLta-K1 (harboring Pita gene) was estimated to harbor Pita gene, because this gene was incompatible with the isolate H-11-64. Resistant gene Pish, Pita 2 and $P i 9$ were thought to be absent in CG II because these materials were susceptible to other three isolates which are virulent to these genes. Materials in $C G$ III group (having differential variety IRBLsh-B with Pish gene) were resistant to H-1-8 but susceptible to other three isolates and considered to harbor Pish gene and not to harbor Pita, Pita 2 and Pi9 gene. Fifteen materials and differential variety, IRBLta2-Pi (harboring Pita2 gene) were resistant to H-1-1 but susceptible to other three isolates and classified as CG IV. These materials were supposed to present Pish gene but not Pita, Pita2 and Pi9 genes. IRBL9-W (harboring Pi9 gene) was susceptible to isolate H-1-1 (compatible to Pi9 gene) among the 4 isolate for primarily estimation of 4 genes. Since other three isolates were incompatible with $P i 9$ gene, IRBL9-W also showed resistant reactions to them. This cultivar was classified as $\mathrm{CG} \mathrm{V}$ and none of the tested materials matched with this cultivar group. Eight materials were resistant to blast isolates, H-11-64 and H-1-8 (Table 2) and classified as CG VI. The reaction pattern of CG VI was corresponded with that of additional effect pattern of IRBLta-CP1 with Pita and IRBLsh-B with Pish. Hence they are considered to harbor Pita and Pish genes. Eleven materials were resistant to 2 isolates, H-11-64 and H-1-1, and estimated to harbor Pita and Pita 2 genes by primary estimation of four genes and classified as CG VII. Thirteen materials were resistant to $\mathrm{H}-1-8$ and $\mathrm{H}-1-1$ isolates and classified as CG VIII. They showed susceptible reaction to other two isolates and thought to harbor Pish and Pita2 genes. Eight cultivars were classified as CG IX as they showed resistance to 3 blast isolates $\mathrm{H}-11-64, \mathrm{H}-1-8$ and $\mathrm{H}-1-1$ but showed compatible reaction to H-11-67. So they are considered to harbor three resistant genes, Pita, Pish and Pita2. Resistance to 4 blast isolate, $\mathrm{H}-11-64, \mathrm{H}-1-8, \mathrm{H}-1-1$ and $\mathrm{H}-11-67$ in cultivars, H100 and H129 (CG X) was recorded where all the 4 primarily estimated genes, Pita, Pish, Pita2 and Pi9 were expected to be present. Genotyping of Pita, Pish, Pita 2 and $P i 9$ genes in tested plant materials was done using diagnostic DNA markers and confirmed the presence of expected genes in the plant materials (Figure 4-7 and Table 3). Similar experiments on the reaction patterns of cultivars and DVs to blast isolates were conducted by many other authors [17, 18]. Their findings were in agreement with the present findings. Kobayashi et al. [15] 
observed various patterns of 42 IRRI-bred cultivars to the differential blast isolates and those cultivars were classified into 7 cultivar groups.

The results of Khan et al. [8] indicated that out of 140 test materials including 114 fragrant germplasms, 25 differential varieties (DVs) harbouring 23 blast-resistant genes, only 16 fragrant rice germplasms showed comparatively better performance against a virulent isolate of blast disease. The reaction pattern of single-spore isolate of Magnaporthe oryzae to differential varieties showed that Pish, Pi9, Pita2 and Pita are the effective blast-resistant genes against the tested blast isolate in Bangladesh. However, the finding of effective blast resistant genes, Pita Pish, Pita2 and Pi9 in this study agreed with those of previous reports. Pyramiding these four resistance genes into existing cultivars would lead to the development of highly resistant rice cultivars [19]. Liu et al. [20] proposed pyramiding (i.e. stacking) several $R$-genes with different resistance spectra into a single rice cultivar to prevent breakdown in blast disease resistance, so that the selection pressure on a single blast isolate would be reduced. However, its success depends largely on a detailed knowledge of both the regional and continental blast population diversity.

Based on this result, tightly linked gene based marker AOL45/AOL48 for Pish, 195R-1/195F-1 for Pi9, OSM89 for Pita2 and Pita440 (YL153/YL154) for Pita were selected for molecular analyses. Tested rice plant materials exhibited DNA band with specific primers on agarose gel electrophoresis. The DNA banding patterns of these cultivars were compared with those of positive and negative control cultivars. These cultivars were also classified into 10 cultivar groups (CG) based on DNA banding patterns with four gene specific primers which was similar to the classification of cultivar group based on reaction patterns to standard blast isolates. From these DNA banding patterns, presence or absence of these 4 genes was estimated in the cultivars for each CG. Based on both the methods of gene estimation, i) reaction to blast isolate and ii) DNA analysis, CG I comprised of fourteen plant materials LTH, US2, H3, H9, H26, H27, H53, H55, H65, H66, H69, H82, H91 and H93 those didn't harbor any resistant gene of expectation. Seven materials IRBLta-K1, H12, H29, H52, H63, H78 and H96 in CG II harbor only Pita gene. In CG III, IRBLsh-B, H40, H61 and H80 harbor Pish gene. Resistant gene Pita2 was present in IRBLta2-Pi, H2, H7, H10, H24, H33, H43, H56, H60, H62 and $\mathrm{H} 98$ in CG IV. Similarly no single Pi9 gene was obtained in CG V. Both Pish and Pita genes were grouped in CG VI comprising of 7 materials $\mathrm{H} 28, \mathrm{H} 36, \mathrm{H} 45, \mathrm{H} 50$, H67, H71 and H141. Both of the gene detection methods gathered H1, H14, H19, H39, H48, H86 and H144 materials in CG VII comprising of Pita and Pita2 genes. Ten materials H15, H16, H21, H22, H37, H42, H57, H72, H79 and H135 with both Pish and Pita2 genes grouped in CG VIII. Similarly three resistant genes, Pita, Pish and
Pita2 were confirmed for H13, H23, H25, H35, H47, H49, H136 and H138 materials. Finally, two materials H100 and H129 exhibited Pita 2 and $P i 9$ genes those showed resistant reaction to all of the tested 4 virulent blast isolates. Resistant frequency of these two materials attributed to $100 \%$ (Table 3) might be due to the presence of broad spectrum $P i 9$ gene together with Pita2 gene.

The detection of DNA fragments in agarose gel electrophoresis for Pi9, Pita, Pish and Pita2 genes and their combinations using specific DNA markers were consistent for above mentioned plant materials with the results of gene estimation using virulent blast analysis. These findings are in accordance with the findings of Fujita et al. [21], Yanoria et al. [22], Mokate et al. [24] and Khan et al. [8]. Koide et al. [23] carried out a detailed study on the resistant genes and selected DNA markers for blast disease in rice. They found effective markers that were tightly linked to the blast resistant genes. Kobayashi et al. [15] confirmed the presence of seven genes through genetic analysis of ten cultivars. Their studies supported the present study.

As expected, single $P i 9$ gene was only detected in two accessions; therefore, more rice entries were needed to screen to detect this gene separately. These germplasms could be extremely useful as the experimental material to develop blast-resistant rice cultivars.

\section{Conclusions}

Source of rice blast resistant gene ( $R$-gene) was identified by host-pathogen interaction and confirmed the presence of those $R$-genes in tested plant materials by PCR-based screening. Four distinct blast isolates (SDBI) having incompatibility reactions to four blast $R$-gene viz. Pish, Pi9, Pita2 and Pita genes classified tested plant materials into 10 cultivar groups (CG). The reaction patterns of those SDBIs indicated presence of those resistant genes and their combination in the genetic background of tested plant materials. Gene specific primers were used to identify and confirm the presence of those $R$-genes in plant materials through PCR-based assay. Three genes, Pita, Pita 2 and Pish were observed together in each of the plant materials of $\mathrm{H} 13, \mathrm{H} 23, \mathrm{H} 25, \mathrm{H} 35, \mathrm{H} 47$, H49, H136, H138 in their genetic background. Only two materials, H100 and H129 were identified having Pi9 gene together with Pita2 through both of the methods. This variability would greatly help researchers in selecting suitable donors in the breeding-for-resistance program meant for transferring particular sets of genes into a desirable background for durable resistance against blast pathogen.

\section{Acknowledgements}

The $\mathrm{PhD}$ researches have been funded by the World 
Bank under NATP-SPGR Sub-Project ID 177. Spatial thanks to Dr. M. A. Taher Mia, Ex-CSO and Head, Plant Pathology Division, BRRI, Gazipur, Bangladesh for his contribution to getting the fund.

\section{REFERENCES}

[1] Timothy ST, Khandaker M, Catherine C, Anwarul H, Nazria I, Saad Q, Yan S 2013: Agriculture and Adaptation in Bangladesh: Current and Projected Impacts of Climate Change. IFPRI (International Food Policy Research Institute) Discussion Paper 01281, pp.76.

[2] MoA 2016: Annual report on the activities of 2015-16. Ministry of Agriculture (MoA), Bangladesh, pp. 200.

[3] Baker B, Zambryski P, Staskawicz B, Dinesh-Kumar SP 1997: Signaling in plant microbe interactions. Science 276: 726-733.

[4] Nelson G, the IFPRI team 2009: Climate change impact on agriculture costs of production. Food Policy Report, International Food Policy Research Institute.

[5] Bevitori R, Ghini R 2015: Rice Blast Disease in Climate Change Times. J Rice Res 3:e111. doi: 10.4172/2375-4338.1000e111.

[6] Greer CA, Webster RK 2001: Occurrence, Distribution, Epidemiology, Cultivar Reaction and Management of Rice Blast Disease in California. Plant Disease 85: 1196-1202.

[7] Notteghem JL, Tharreau D, Silue D, Roumen E 1994: Present knowledge on rice resistance genetics and strategies for analysis of $M$. grisea pathogenicity and avirulence genes. In Rice Blast Disease, R. Zeigler, S.A. Leong, and P.S. Teng, eds (Wallingford, UK: Commonwealth Agricultural Bureau International), pp. 155-166.

[8] Khan MAI, Sen PP, Bhuiyan R, Kabir E, Chowdhury AK, Fukuta Y, Ali A, Latif MA 2014: Phenotypic screening and molecular analysis of blast resistance in fragrant rice for marker assisted selection. Comptes Rendus Biologies 337 (5): 318-324.

[9] Hossain M 2014: Identification of existing races of Pyricularia grisea in rice in Bangladesh using monogenic lines of rice. A dissertation on doctor of philosophy. Department of Plant Pathology, Bangladesh Agricultural University, Mymensingh, pp. 218.

[10] Hayashi N, Kobayashi N, Vera Cruz CM, Fukuta Y 2009: Protocol for the sampling of diseased specimens and evaluation of blast disease in rice. JIRCAS Working Report No. 63: 17-33.

[11] Hayashi N, Fukuta Y 2009: Proposal for a new international system of differentiating races of blast (Pyricularia oryzae Cavara) by using LTH monogenic lines in rice (Oryza sativa L.). In: JIRCAS working report No. 63. Development and Characterization of Blast Resistance Using Differential Varieties in Rice. Fukuta Y., Vera Cruz C. M. and Kobayashi N. (Eds). JIRCAS, Tsukuba, Japan.
[12] Collard BCY, Das A, Virk PS, Mackill DJ 2007: Evaluation of 'quick and dirty' DNA extraction methods for marker-assisted selection in rice (Oryza sativa L.). Plant Breeding 126: 47-50.

[13] Neeraja, C. N., R. Maghirang-Rodriguez, A. Pamplona, S. Heuer, B. C. Y. Collard, E. M. Septiningsih, G. Vergara, D. Sanchez, K. Xu, A. M. Ismail and D. J. Mackill. 2007. A marker-assisted backcross approach for developing submergence-tolerant rice cultivars. Theory and Applied Genetics 115(6): 767-776.

[14] Jean-Louis V 2000: Electrophoresis of DNA and other polyelectrolytes: Physical mechanisms. Reviews of Modern Physics 72: 813-872.

[15] Kobayashi N, Ebron LA, Fujita D, Fukuta Y 2009: Identification of blast resistant genes in IRRI-bred rice varieties by segregation analysis based on a differential system. JIRCAS working report no. 63: 69-86.

[16] Mahender A, Swain DM, Gitishree D, Subudhi HN, Rao JN 2012: Molecular analysis of native Manupuri rice accessions for resistance against blast. African Journal of Biotechnology 11: 1321-1329.

[17] Ebron LA, Fukuta Y, Imbe T, Kato H, Yanoria JMT, Tsunematsu H, Khush GS, Yokoo M 2004: Estimate of genes in blast resistance in elite Indica-type rice (Oryza sativa $\mathrm{L}$.) varieties bred at the International Rice Research Institute. Breeding Science 54: 381-387.

[18] Fukuta Y, Ebron LA, Kobayashi N 2007: Genetic and breeding analysis of blast resistance in elite indica-type rice (Oryza sativa L.) bred in International Rice Research Institute. JARQ 41: 101-114.

[19] Mackey D, Holt BF, Wiig A, Dangl JL 2002: RIN4 interacts with Pseudomonas syringae type III effector molecules and is required for RPM1-mediated resistance in Arabidopsis. Cell 108: 743-754.

[20] Liu J, Wang X, Mitchell T, Hu Y, Liu X, Dai L, Wang GL 2010: Recent progress and understanding of the molecular mechanisms of the rice-Magnaporthe oryzae interaction. Molecular Plant Pathology 11(3): 419-427.

[21] Fujita D, Leodegario AE, Kobayashi N, Fukuta Y 2009: Comparison of DNA marker analysis of the blast resistance genes Pib and Pita in IRRI-bred rice varieties with gene estimation by conventional genetic analysis. JIRCAS Working Report No. 63: 87-94.

[22] Yanoria MJT, Imbe T, Kato H, Tsunematsu H, Ebron LA, Vera Cruz, Kobayashi N, Fukuta Y 2008: A set of standard differential blast isolates (Pyricularia grisea (Cooke) Sacc.) from the Philippines for rice (Oryza sativa L.) resistance. JARQ 42: 23-34.

[23] Koide Y, Kobayashi N, Xu D, Fukuta Y 2009: Blast resistance genes and their selection markers in rice (Oryza sativa L.). JIRCAS Working Report No. 63: 95-122.

[24] Mokate AS, Mehetre SS, Bendale VW, Birari SP 1998: Genetic divergence in rice, Advanced Plant Science 11: 197198. 